\title{
Comparison of the Maternal and Neonatal Effects of Intratechal Bupivacaine Plus Fentanyl or Morphine During Cesarean Delivery
}

\author{
Elektif Sezaryen Seksiyolarda Intratekal Bupivakaine Eklenen Fentanil ve Morfinin \\ Maternal ve Yenidoğan Üzerine Etkileri
}

\author{
Ahmet Yıldıım, Ferhunde Dilek Subaşı*, Yıldız Kuplay** , Güldem Turan** , Osman Ekinci*, \\ Gülşen Bosna* \\ Ümraniye Training and Research Hospital, Anesthesiology and Reanimation, istanbul, Turkey \\ *Haydarpaşa Numune Training and Research Hospital, Anesthesiology and Reanimation, istanbul, Turkey \\ ${ }^{* *}$ Fatih Sultan Mehmet Training and Research Hospital, Anesthesiology and Reanimation, istanbul, Turkey
}

\section{Abstract}

Aim: To evaluate the effects of morphine and fentanyl added to bupivacaine and intrathecal bupivacaine to combine spinal-epidural anaesthesia during caesarean.

Methods: Forty subjects with American Society of Anesthesiologists I-Il status who would have caesarean were included in the study. The subjects were divided into two groups. Group bupivacaine-fentanyl (BF) were given $0.5 \%$ bupivacaine $7.5 \mathrm{mg}+25 \mu \mathrm{g}$ fentanyl and group bupivacaine-morphine (BM) received $0.5 \%$ bupivacaine 7.5 $\mathrm{mg}+0.1 \mathrm{mg}$ morphine intrathecal total $2 \mathrm{~mL}$. Periods for access to T4 block, two dermatome regression of sensory block, time elapsed between the administration of the local anaesthetic and reaching Bromage scale 1, reaching the highest level of motor block, first analgesic necessity, umbilical cord clamping time, and when the operation ends were recorded. One-minute and five-minute Apgar scores, umbilical blood gas values of the newborns and the adverse effects were recorded.

Results: Comparisons between the two groups show that group BM has longer periods for motor block start time, two dermatome regression time, and first anaesthetic necessity time and group BF had higher levels for motor block level at the $1^{\text {st }}$ minute and visual analog scale scores at postop $60^{\text {th }}$ minute. There was no significant difference between the groups for the adverse effects.

Conclusion: Fentanyl and morphine added to intrathecal bupivacaine show similar effects in intraoperative analgesia. We
Amaç: Sezaryenlerde kombine spinal-epidural anestezide intratekal bupivakain ve bupivakaine eklenen fentanil ve morfinin etkilerini değerlendirmektir.

Yöntemler: Sezaryen operasyonu geçirecek Amerikan Anestezi Derneği I-II grubunda, 40 olgu çalışmaya alındı. Olgular iki gruba ayrıld. Grup bupivakain-fentanile (BF) 7,5 mg \%0,5 bupivakain +25 $\mu \mathrm{g}$ fentanil, grup bupivakain-morfine (BM) 7,5 mg \%0,5 bupivakain $+0,1 \mathrm{mg}$ morfin intratekal olarak total $2 \mathrm{~mL}$ verildi. T4 duyusal bloğa ulaşma, duyusal bloğun iki dermatom gerileme, lokal anestezinin verilmesinden Bromage skalasının 1 olma süreleri, motor bloğun en üst skalaya ulaşma süresi, motor bloğun tamamen kaybolma süresi, ilk analjezik ihtiyacı süresi, bebeğin umblikal korda klemp konma süresi, operasyon bitim süresi kaydedildi. Olguların deri ve uterus insizyonu, periton kapatma, postoperatif 30 dakika, 60 dakika ve ağı duydukları andaki ağrı şiddetleri ve ulaşılan en üst motor blok skalası kaydedildi. Yenidoğan birinci-beşinci dakika Apgar değerleri ve umblikal kan gazı değerleri ve yan etkiler kaydedildi.

Bulgular: Gruplar arasında yapılan karşılaştırmalarda, grupların motor blok başlama zamanı, iki dermatom gerileme süresi, ilk analjezik intiyacı süresi grup BM'de uzun bulunurken, birinci dakika motor blok seviyesi ve postop 60 dakika visuel analog skalaları ise grup $\mathrm{BF}^{\prime}$ de daha yüksek bulundu. Yan etkiler açısından gruplar arasında anlamlı farklılık bulunmadı.
Address for Correspondence/Yazışma Adresi: Ahmet Yıldırım

Ümraniye Training and Research Hospital, Anesthesiology and Reanimation, İstanbul, Turkey E-mail: drahmetyildirim1975@yahoo.com

Received/Geliş Tarihi: 11 March 2016 Accepted/Kabul Tarihi: 20 March 2016
The Medical Bulletin of Haseki Training and Research Hospital, published by Galenos Publishing.

Haseki Tıp Bülteni, Galenos Yayınevi tarafından basılmıştır. 
have deduced that although low doses of hyperbaric bupivacaine is effective during caesarean section, fentanyl and morphine added to bupivacaine can also be used safely and effectively.

Keywords: Pupivacaine, cesarean, fentanyl, morphine
Sonuç: Intratekal bupivakaine eklenen fentanil ve morfin benzer intraoperatif analjezi sağladı. Sezaryenlerde hiperbarik bupivakainin düşük dozlarda da etkili olduğu, bupivakaine eklenen fentanil ve morfinin sezaryenlerde etkin şekilde ve güvenle kullanılabilir olduğu sonucuna varıldı.

Anahtar Sözcükler: Bupivakain, sezaryen, fentanil, morfin

\section{Introduction}

Cesarean delivery can be done with general or regional anesthesia. In cesarean section (CS) regional anesthesia is preferred against general anesthesia because of the lower effect on airway, lower aspiration risk, higher consciousness during surgery, and lower uterine atonia which is a dangerous complication (1). After the discovery of opioid receptors in the cortex and spinal cord, intrathecal opioids are commonly used for analgesia. Hydrophilic opioids, such as morphine have small distribution volume and slow diffusion in the spinal cord and deliver a great spinal analgesia. Hydrophilicity may lead to slow spinal cord penetration and, therefore, elongated effect in the cerebrospinal fluid and prolonged anesthesia recovery resulting in respiration depression. Lipophilic opioids have faster anesthesia start time, longer block time and minimal respiratory depressive effects. Using small doses of fentanyl added to bupivacaine increases the postoperative analgesia time and decreases the usage of antiemetics. Intrathecal morphine shows a longer postoperative analgesia than fentanyl $(2,3)$. The aim of this study was to compare the postoperative analgesic effects of $7.5 \mathrm{mg}$ $0.5 \%$ bupivacaine combined with $25 \mu \mathrm{g}$ fentanyl and that combined with $0.1 \mathrm{mg}$ morphine in elective CS operations.

\section{Methods}

Forty pregnant women with American Society of Anesthesiologists (ASA) physical status I-II aged 18-45 years included in the study. The study protocol was approved by the Haydarpaşa Numune Training and Research Hospital of Local Ethics Committee. All patients provided written informed consent to participate in this study. Patients who needed urgent CS and/or had contraindication for regional anesthesia were excluded from the study. One patient from the bupivacaine-fentanyl (BF) group was excluded because of the need for epidural supplementation after spinal anesthesia. Thirty-nine patients were evaluated.

The patients were randomly assigned to one of two groups according to computer-generated random number codes placed in sealed envelopes. Combined spinal-epidural anesthesia (CSEA) was chosen for regional anesthesia. Both groups were hydrated with $15 \mathrm{~mL} / \mathrm{kg}$ of normal saline 15-20 minutes before the procedure.
CSEA was applied with the patients in the sitting position and L3-4 or L4-5 was used for the needle insertion. An 18-gauge (G) tuohy needle was used with loss of resistance technique to enter the epidural space and after that, needle-through-needle method was used with 27-G spinal needle to enter the intrathecal space. Group BF received intrathecal administration of $7.5 \mathrm{mg} 0.5 \%$ hyperbaric bupivacaine $(1.5 \mathrm{~mL})+25 \mu \mathrm{g}$ fentanyl $(0.5 \mathrm{~mL})$ and Group BM received intrathecal administration of $7.5 \mathrm{mg} 0.5 \%$ hyperbaric bupivacaine $(1.5 \mathrm{~mL})+0.1 \mathrm{mg}$ morphine $(0.5$ $\mathrm{mL}$ ). To equalize the volume, both drugs were diluted with $2 \mathrm{~mL}$ of normal saline. After spinal injection and the epidural catheter was placed, the patients were positioned in 10-degree trendelenburg position. The patients were placed in the supine position after the sensorial block reached to $T_{4}$. All the parameters were evaluated with another anesthesiologist who was blind to the groups.

Systolic blood pressure (SBP), diastolic blood pressure, mean arterial pressure (MAP), heart rate (HR) and peripheral oxygen saturation $\left(\mathrm{SpO}_{2}\right)$ values were recorded at $1^{\text {st }}, 3^{\text {rd }}$, and $5^{\text {th }}$ minutes, and five minutes intervals thereafter. More than $30 \%$ of decrease in the MAP from the baseline or a SBP of less than $90 \mathrm{mmHg}$ was defined as hypotension and was treated with $5 \mathrm{~mL} / \mathrm{kg}$ fluid infusion and $5 \mathrm{mg}$ ephedrine intravenously. Total ephedrine doses were recorded. A HR of less than 50 beats/minute was defined as bradycardia and was treated with atropine 0.5 mg intravenously.

Sensorial and motor block levels at $1^{\text {st }}, 3^{\text {rd }}$ and $5^{\text {th }}$ minutes were recorded. The level of sensorial block was tested using pin-prick test and motor block was assessed by the Bromage scale $(0=$ full flexion of knees and feet, $1=$ just able to move knees, $2=$ able to move feet only, $3=$ unable to move feet or knees). Time to attain $\mathrm{T}_{4}$ sensory block (t1), time for two-dermatomes of regression in sensory block (t2), time from administration of local anesthesia to reaching Bromage scale ' 1 ' ( $\mathrm{t} 3$ ), time for the motor block to reach the highest level ( $t 4)$, time from administration of local anesthesia until the baby is born and umbilical cord is clamped (t5), time from administration of local anesthesia until the end of the operation (t6), time for complete resolution of the motor block (t7), and time to the first requirement of analgesia in postoperative period 
(t8) were recorded. The maximum level of motor and sensorial block and also motor block levels at $1^{\text {st }}, 3^{\text {rd }}$ and $5^{\text {th }}$ minutes were recorded.

Pain scores were recorded during skin incision, uterine incision, and peritoneal closure on the postoperative $30^{\text {th }}$ and $60^{\text {th }}$ minutes and on the first pain sensation postoperatively. Pain intensity was assessed by using a 10-cm visual analogue scale (VAS). A VAS of "0" was defined as "no pain" and "10" was defined as "worst possible pain". When the patient had pain during the procedure (VAS 3-4), supplemental opioid (fentanyl $50 \mu \mathrm{g}$ ) and sedation was administered. Nevertheless, in the case of inadequate anesthesia, epidural supplementation was performed and these patients were excluded from the study. The number of subjects who received supplemental anesthesia was recorded.

Apgar scores at the $1^{\text {st }}$ and $5^{\text {th }}$ minutes and umbilical vein blood gas analysis of the newborn were recorded.

Pruritus, nausea, vomiting, anxiety, respiratory depression and headache were recorded during the operation. Pruritus, nausea and vomiting were classified as mild, moderate and severe. Moderate pruritus was treated with naloxone [40-80 $\mu \mathrm{g}$ intravenous (iv)] and nausea and vomiting were treated with ondansetron (4-8 mg iv).

Statistical analysis was performed by using SPSS 17.0 software package program. The results were analyzed using descriptive statistical methods (mean, standard deviation, frequency) and the independent samples t-test for group comparison and paired sample t-test for intragroup comparisons to evaluate quantitative results. For the comparison of group distribution, Fisher's exact test and chi-square test were used. The results were analyzed at 95\% confidence interval and a $p$ value of less than 0.05 was considered statistically significant.

\section{Results}

There were no significant differences between the groups in age, weight, height, gestational age, and ASA physical status (Table 1).

There was a statistically significant difference between the groups with respect to interval between local anesthetic administration and motor block reaching to Bromage scale score $1 \mathrm{t} 3$, time required for sensory block to two dermatomes $t 2$ and time to postoperative first analgesic requirement ' $t 8$ ' $(p<0.05)$. The time for the motor block to reach maximum level t4, duration of motor block $\mathrm{t} 7$, time to motor block to reach $\mathrm{T}_{4}$ level $\mathrm{t} 1$, interval between intrathecal injection and delivery $\mathrm{t} 5$ and duration of surgery t7 were similar between the groups (Table 2).

During skin incision and uterine incision, all patients' VAS scores were found to be 0 in both groups. Pain scores at peritoneum closure and on postoperative $30^{\text {th }}$ minute were similar between the groups while there was a significant difference in pain scores on postoperative $60^{\text {th }}$ minute between the groups (Table 3).

Neonatal $1^{\text {st }}$ and $5^{\text {th }}$ minute Apgar scores and umbilical vein blood gas $\mathrm{pH}, \mathrm{pCO}_{2}$ and $\mathrm{pO}_{2}$ values were similar between the groups $(p>0.05)$.

\section{Discussion}

The purpose of obstetric anesthesia is to ensure the maternal and fetal safety without affecting the birth process negatively, as well as comforting the mother. Spinal techniques have become prominent by increasing the analgesia quality and achievement drive, due to having prompt effect, however, it is also considered that this prompt effect is associated with more side effects, compared to other regional techniques (4). At this point, the need for the discovery of medication combinations to enable the desired ideal conditions has emerged. Adding opioid to intrathecal local anesthetics in order to increase the quality of perioperative analgesia is a method increasingly used in recent years. It also allows the use of very low doses of local anesthetic, which contributes to more stable hemodynamics $(5,6)$.

It is emphasized that the use of local anesthetics together with intrathecal opioids causes antinociceptive synergy in visceral and somatic nociception. Adding lipophilic opioids like fentanyl to local anesthetics precipitates the onset of the effect and increases the analgesia quality during the intraoperative and postoperative periods. In case of the intrathecal morphine use, which is highly ionized, the onset of the effect is later but the duration of the effect is longer. The purpose of the spinal anesthesia with low-dose local anesthetics is to retain the cardiovascular stability and to ensure a better post-operative analgesia by adding opioid. There are studies indicating that as a local anesthetic, hyperbaric bupivacaine provides a sufficient level of anesthesia even by a low-dose $(7,8)$. For our study, we planned the local anesthetic dose as $7.5 \mathrm{mg}$.

\begin{tabular}{|c|c|c|c|c|}
\hline & & Group BF & Group BM & \multirow{2}{*}{ p } \\
\hline & & Mean \pm SD & Mean \pm SD & \\
\hline \multicolumn{2}{|c|}{ Age (years) } & $29.21 \pm 3.98$ & $27.30 \pm 3.90$ & 0.139 \\
\hline \multicolumn{2}{|c|}{ Weight (kg) } & $74.74 \pm 9.98$ & $75.60 \pm 9.58$ & 0.785 \\
\hline \multicolumn{2}{|c|}{ Height $(\mathrm{cm})$} & $160.16 \pm 4.42$ & $160.90 \pm 5.05$ & 0.629 \\
\hline \multirow{2}{*}{\multicolumn{2}{|c|}{ Gestational age (day) }} & $271.74 \pm 6.33$ & $273.75 \pm 8.91$ & 0.424 \\
\hline & & n (\%) & $n(\%)$ & $p$ \\
\hline \multirow{2}{*}{ ASA } & 1 & $4(21 \%)$ & 7 (35\%) & \multirow{2}{*}{0.480} \\
\hline & 11 & $15(79 \%)$ & $13(65 \%)$ & \\
\hline
\end{tabular}


Another key point for providing analgesia in CS is to use the optimum opioid dose to minimize the risk for the mother and the newborn. While choosing the combinations for the use of local anesthetics together with the opioids requires the consideration of at least three components which can be grouped as; sensory and motor blockade and its duration; post-operative analgesia quality and duration as well as possible side-effects for the mother and the newborn. Intrathecal morphine at a dose of 0.1-0.2 mg and fentanyl at a dose of 10-25 $\mu \mathrm{g}$ are commonly used for obstetric analgesia $(9,10)$. During our study, we compared $25 \mu \mathrm{g}$ fentanyl $(0.5 \mathrm{~mL})$ and 0.1 $\mathrm{mg}$ morphine $(0.5 \mathrm{~mL})$, both supplemented with $7.5 \mathrm{mg}$ hyperbaric bupivacaine, used for elective CS cases.
Intrathecal opioids can be divided into two groups as lipophilic and hydrophilic, based on their lipid solubility. Morphine is in the hydrophilic group, while fentanyl, alfentanil and sulfentanil are in the lipophilic opioids group. Lipophilic opioids quickly diffuse across the spinal membranes and the spinal cord; and their effect starts quickly where hydrophilic opioids pass to these tissues more slowly, and for this reason, their effect starts later compared to the lipophilics (11-13). However, lipophilic opioids are absorbed by the vascular system and adipose tissue and removed sooner, and their duration of effect lasts shorter compared to the hydrophilic opioids. Sibilla et al. (14) compared lipophilic and hydrophilic opioids in their CS operations and confirmed that the post-operative analgesia quality provided by 12-14 mg bupivacaine

\begin{tabular}{|l|l|l|}
\hline \multicolumn{2}{|l|}{ Table 2. Comparison of groups in terms of procedural times } & Group BM \\
\hline & Group BF & Mean \pm SD \\
\hline & Mean \pm SD & $316.25 \pm 55.12$ \\
\hline $\begin{array}{l}\text { Sensorial block reach to T level } \\
\text { t1 (second) }\end{array}$ & $304.26 \pm 110.99$ & $87.95 \pm 03.56$ \\
\hline Two dermatomal level regression of sensorial block t2 (minute) & $82,74 \pm 07,13$ & $133.00 \pm 38.74$ \\
\hline $\begin{array}{l}\text { Motor block reach to Bromage 1 } \\
\text { t3 (second) }\end{array}$ & $97.89 \pm 42.82$ & $251.25 \pm 58.98$ \\
\hline $\begin{array}{l}\text { Maximal level of motor block } \\
\text { t4 (second) }\end{array}$ & $250.26 \pm 85.59$ & $16.90 \pm 03.55$ \\
\hline Time to delivery and umblical cord clemping t5 (minute) & $19.11 \pm 06.02$ & $61.50 \pm 09.82$ \\
\hline End of surgery time t6 (minute) & $67.74 \pm 13.39$ & 0.006 \\
\hline Time to motor block completely disappear t7 (minute) & $177.95 \pm 09.83$ & 0.967 \\
\hline First analgesic requirement postoperatively t8 (minute) & $173.05 \pm 10.74$ & $187.30 \pm 10.82$ \\
\hline BF: Bupivacaine-fentanyl, BM: Bupivacaine-morphine, SD: Standard deviation, $p<0.05$ & & 0.17 \\
\hline
\end{tabular}

\begin{tabular}{|c|c|c|c|c|}
\hline \multirow{2}{*}{\multicolumn{2}{|c|}{$n(\%)$}} & Group BF & Group BM & \multirow{2}{*}{$\mathbf{p}$} \\
\hline & & \multirow{2}{*}{\begin{tabular}{|l|}
$\mathbf{n}(\%)$ \\
$14(73.6 \%)$ \\
\end{tabular}} & \multirow{2}{*}{$\begin{array}{l}\mathbf{n}(\%) \\
15(75 \%)\end{array}$} & \\
\hline \multirow{7}{*}{ Peritoneum closure } & 0 & & & \multirow{7}{*}{0.422} \\
\hline & 3 & $2(10.5 \%)$ & 0 & \\
\hline & 4 & 0 & $1(5 \%)$ & \\
\hline & 5 & $1(5.3 \%)$ & $1(5 \%)$ & \\
\hline & 6 & $1(5.3 \%)$ & $1(5 \%)$ & \\
\hline & 7 & 0 & $2(10 \%)$ & \\
\hline & 8 & $1(5.3 \%)$ & 0 & \\
\hline \multirow{3}{*}{$\begin{array}{l}\text { Postoperative } \\
30^{\text {th }} \text { minute }\end{array}$} & 0 & $16(84.2 \%)$ & $20(100 \%)$ & \multirow{3}{*}{0.181} \\
\hline & 1 & $2(10.5 \%)$ & 0 & \\
\hline & 3 & $1(5.3 \%)$ & 0 & \\
\hline \multirow{3}{*}{$\begin{array}{l}\text { Postoperative } \\
60^{\text {th }} \text { minute }\end{array}$} & 0 & $8(42.1 \%)$ & $19(95 \%)$ & \multirow{3}{*}{0.002} \\
\hline & 1 & $7(36.8 \%)$ & $1(5 \%)$ & \\
\hline & 2 & $4(21.1 \%)$ & 0 & \\
\hline
\end{tabular}


added to $25 \mu \mathrm{g}$ fentanyl was lower than $0.1 \mathrm{mg}$ morphine and that fentanyl had an effect similar to placebo. In other studies in which intrathecal fentanyl and morphine have been used, the analgesic quality and first analgesic usage time in patients receiving morphine was longer than those receiving fentanyl $(15,16)$. In our study, the mean post-operative analgesia duration was found to be 187.85 minutes in BM group, while it was 173.05 minutes in BF group and, the difference was statistically significant. In addition, when VAS scores were compared, lower VAS values were obtained in BM group. Penetration of morphine and fentanyl into the spinal cord and their clearance from the spinal cord (depend on lipid solubility) cause these differences.

Intrathecal anesthesia may cause undesirable reactions like nausea and vomiting. In spite of blockade which can go up to $T_{4}$ level, the patient can feel discomfort for the visceral pulling, especially when the uterus is taken out. In their study, Sibilla et al. (14) compared the effects of intrathecal fentanyl and morphine and they confirmed that nausea and vomiting incidents were less common in fentanyl group compared to morphine group. In our study, nausea and vomiting were observed in $50 \%$ and $20 \%$ of patients of BM group, respectively, while these rates were $26.3 \%$ and $10.5 \%$ in BF group, respectively. The cause of nausea and vomiting was considered to be visceral pulling in the phases of the uterus being taken out and the closure of the peritoneum.

As it has been previously reported, pruritus is a common side effect of intrathecal use of fentanyl (17). In a study by Mulroy et al., (18) 33 patients received lidocaine and fentanyl, 47 received bupivacaine and fentanyl, and 55 patients were administered procaine and fentanyl. It was observed that $55 \%$ of patients of BF group experienced itching. Comparing the effect of intrathecal fentanyl and morphine; Sibilla et al. (14) found that the incident of pruritus was higher in morphine group. In our study, pruritus was observed in both groups with the same percentage.

Use of local anesthetics combined with intrathecal opioid can provide a better hemodynamic stability. Shende et al. (19) confirmed that $12.5 \mathrm{mg} 15 \mu \mathrm{g}$ fentanyl added to $12.5 \mathrm{mg} 0.5 \%$ bupivacaine shortens the duration of the first ephedrine need, but does not affect the total ephedrine need. The fact that it shortens the time to the first ephedrine need is interpreted as the opioids quicken the sympathetic blockade. The incidence of hypotension has been reported to be $45 \%$ in spinal anesthesia practice in cesarean operations and, hydration, left lateral position and use of vasoconstrictor agents are recommended for prevention. Ephedrine use for this purpose may cause maternal reactive hypertension, tachycardia, tachyphylaxis and, with the decline of uterine blood stream, fetal acidosis $(20,21)$. Hypotension and bradycardia observed in spinal anesthesia result from the negative effect of the local anesthetics on the sympathetic blockade and the afferent heart conduction system in $\mathrm{T}_{4}$ dermatomal level, and the side effects of the opioids. In our study, hypotension occurred with the percentage of 52.6 in BF group and with the percentage of 45 in BM group, and in addition, bradycardia emerged with the percentage of 15.8 in BF group. We suppose that bradycardia occurred as a result of fentanyl-related vagal stimulation. No significant difference was identified between the groups with regard to the hypotension and the amounts of ephedrine used.

It has been reported that inclusion of fentanyl or morphine into intrathecal bupivacaine does not affect Apgar score and the newborn blood gas level in cesareans. Arzola and Wieczorek (22) in their review of randomised controlled trials of low dose spinal bupivacaine $(\leq 8 \mathrm{mg}$ ) versus conventional dose spinal bupivacaine $(>8 \mathrm{mg})$ in elective or semi-urgent caesarean delivery under neuraxial spinal anaesthesia, they concluded that there was no significant difference in neonatal outcomes, such as Apgar score and acid-base status and clinical quality variables, such as patient satisfaction and surgical conditions, between patients receiving low dose bupivacaine and those receiving conventional dose bupivacaine. Blood $\mathrm{pH}$ and acid-base balance of the umbilical cord is another objective indicator of neonatal wellness. In our study, no significant difference was observed between the two groups in the Apgar scores. When umbilical cord venous blood gas analysis was evaluated, it was observed that the $\mathrm{pH}$ values in both groups were significantly higher and $\mathrm{pO}_{2}$ values were significantly lower than the normal ranges. In our study, no significant difference was detected between $\mathrm{BF}$ and $\mathrm{BM}$ groups in intraoperative and postoperative patient satisfaction and the preference of the same anesthesia method for the future. No headache complains were observed in both groups.

Although intrathecal use of hyperbaric BF or hyperbaric BM combinations in cases of elective CS operations have similar anesthetic efficacy and effects on the newborn, we concluded that a BM combination is advantageous in terms of the requirement for postoperative analgesia.

\section{Ethics}

Ethics Committee Approval: The study were approved by the Haydarpaşa Numune Training and Research Hospital of Local Ethics Committee, Informed Consent: Consent form was filled out by all participants.

Peer-review: External and Internal peer-reviewed. 


\section{Authorship Contributions}

Surgical and Medical Practices: Ahmet Yıldırım, Ferhunde Dilek Subaşı, Yıldız Kuplay. Concept: Ahmet Yıldıım, Ferhunde Dilek Subaşı, Yıldız Kuplay. Design: Ahmet Yıldırım, Ferhunde Dilek Subaşı, Yıldız Kuplay. Data Collection or Processing: Ahmet Yıldırım, Ferhunde Dilek Subaşı, Yıldız Kuplay, Güldem Turan. Analysis or Interpretation: Ahmet Yıldırım, Ferhunde Dilek Subaşı, Yıldız Kuplay, Güldem Turan, Osman Ekinci, Gülşen Bosna. Literature Search: Ahmet Yıldırım, Ferhunde Dilek Subaşı, Yıldız Kuplay, Güldem Turan, Osman Ekinci, Gülşen Bosna. Writing: Ahmet Yıldırım.

Conflict of Interest: No conflict of interest was declared by the authors.

Financial Disclosure: The authors declared that this study has received no financial support.

\section{References}

1. Wong CA. General anesthesia is unacceptable for elective cesarean section. Int J Obstet Anesth 2010;19:209-12.

2. Ayaub CM, Sinatra RS. Postoperative analgesia epidural and spinal techniques. In: DH C, editor. Obstetric anesthesia. 2004. 3rd ed. Pennsylvania: Mosby.

3. Hamber EA, Viscomi CM. Intrathecal lipophilic opioids as adjuncts to surgical spinal anesthesia. Reg Anesth Pain Med 1999;24:255-63.

4. Vercauteren M. Obstetric spinal analgesia and anesthesia. Curr Opin Anaesthesiol 2003;16:503-7.

5. Choi DH, Ahn HJ, Kim MH. Bupivacaine-sparing effect of fentanyl in spinal anesthesia for cesarean delivery. Reg Anesth Pain Med 2000;25:240-5.

6. Ben-David B, Miller G, Gavriel R, et al. Low-dose bupivacainefentanyl spinal anesthesia for cesarean delivery. Reg Anesth Pain Med 2000;25:235-9.

7. Van de Velde M, Van Schoubroeck D, Jani J, et al. Combined spinal-epidural anesthesia for cesarean delivery: dose-dependent effects of hyperbaric bupivacaine on maternal hemodynamics. Anesth Analg 2006;103:187-90.

8. Roofthooft E, Van de Velde M. Low-dose spinal anaesthesia for Caesarean section to prevent spinal-induced hypotension. Curr Opin Anaesthesiol 2008;21:259-62.

9. Evron S, Ezri T. Low-dose versus a higher-dose bupivacaine spinal anesthesia for cesarean delivery. Anesthesiology 2009;111:213.
10. Geng ZY, Wang DX, Wu XM. Minimum effective local anesthetic dose of intrathecal hyperbaric ropivacaine and bupivacaine for cesarean section. Chin Med J (Engl) 2011;124:509-13.

11. Parlow JL, Money P, Chan PS, et al. Addition of opioids alters the density and spread of intrathecal local anesthetics? An in vitro study. Can J Anaesth 1999;46:66-70.

12. Wang C, Chakrabarti MK, Whitwam JG. Specific enhancement by fentanyl of the effects of intrathecal bupivacaine on nociceptive afferent but not on sympathetic efferent pathways in dogs. Anesthesiology 1993;79:766-73.

13. Barkshire K, Russell R, Burry J, et al. A comparison of bupivacaine-fentanyl-morphine with bupivacaine-fentanyldiamorphine for caesarean section under spinal anaesthesia. Int J Obstet Anesth 2001;10:4-10.

14. Sibilla C, Albertazz P, Zatelli R, et al. Perioperative analgesia for caesarean section: comparison of intrathecal morphine and fentanyl alone or in combination. Int J Obstet Anesth 1997;6:43-8.

15. Akay S, Ayoğlu H, Yurtlu BS, et al. Comparison of the effects of intrathecal levobupivacaine plus fentanyl and morphine combination in caesarean section. Turk J Anaesth Reanim's 2009;37:25-34.

16. Karaman S, Gunusen I, Uyar M, et al. The effects of morphine and fentanyl alone or in combination added to intrathecal bupivacaine in spinal anesthesia for cesarean section. Agri 2011;23:57-63.

17. Akcaboy EY, Akcaboy ZN, Gogus N. Low dose levobupivacaine $0.5 \%$ with fentanyl in spinal anaesthesia for transurethral resection of prostate surgery. J Res Med Sci 2011;16:68-73.

18. Mulroy MF, Larkin KL, Siddiqui $A$. Intrathecal fentanylinduced pruritus is more severe in combination with procaine than with lidocaine or bupivacaine. Reg Anesth Pain Med 2001;26:252-6.

19. Shende D, Cooper GM, Bowden MI. The influence of intrathecal fentanyl on the characteristics of subarachnoid block for caesarean section. Anaesthesia 1998;53:706-10.

20. Mercier FJ, Riley ET, Frederickson WL, et al. Phenylephrine added to prophylactic ephedrine infusion during spinal anesthesia for elective cesarean section. Anesthesiology 2001;95:668-74.

21. Ngan Kee WD, Lau TK, Khaw KS, et al. Comparison of metaraminol and ephedrine infusions for maintaining arterial pressure during spinal anesthesia for elective cesarean section. Anesthesiology 2001;95:307-13.

22. Arzola C, Wieczorek PM. Efficacy of low-dose bupivacaine in spinal anaesthesia for Caesarean delivery: systematic review and meta-analysis. Br J Anaesth 2011;107:308-18. 